\title{
Yaş Üzüm Nakliyesi: Denizli Çal Bölgesi Örneği
}

\author{
Derya Nermin DERELi' ${ }^{1}$
}

Aydın SARI ${ }^{2}$

\section{Öz}

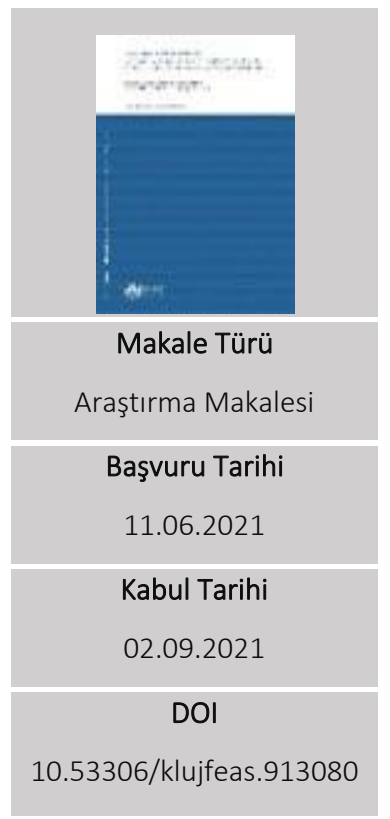

Yurtiçi ve yurtdışı yaş meyve sebze nakliyesi tüm ülkelerde daha teknolojik ve sağlıklı koşullarda yapılabilmesi için yeni sistemler arayışı içindedir. Çalışmada ülkemizin her bölgesinde bol miktarda üretimi yapılan üzümün nakliyesi ele alınarak, Denizli Çal bölgesinde nakliye yapısını ortaya koymaktır. Ürünün olgunlaşmasından itibaren depolama imkanları, nakliye senkronizesi, paketleme ve uygun araç seçimi gibi konular ele alınmıştır. Buna göre nakliye araçlarının dünya ölçeğine göre uygun olduğu diğer taraftan ürünün depolanması ve paketlemesi konularından yetersiz kaldığı görülmektedir. Özellikle depo eksikliği ve uygun olmayan paketleme ürünün ihracatını olumsuz yönde etkilediği anlaşılmıştır. Diğer taraftan havayolu kargo ile üzüm nakliyesinin olmadığı ortaya çıkmıştır. Ürünlerin ağılıklı olarak karayolu ile yurtiçi ve yurtdışına sevk edildiği anlaşıımıştır. Gıda taşımacılığının geliştirilmesi ile maliyetlerin düşmesi ürün kaybının minimize edilmesi amacıyla çalışmanın önerileri sonuç kısmında verilmiştir.

Anahtar sözcükler: bozulabilir kargo, üzüm, yaş meyve nakliyesi, Denizli Çal bölgesi

\footnotetext{
${ }^{1}$ Sorumlu Yazar: Ziraat Yük. Mühendisi, Ege Üniversitesi, Ziraat Fakültesi, Tarım Ekonomisi Bölümü, Tarım Politikası ve Yayım Anabilim Dalı, deryanermin@gmail.com, ORCID: 0000-0002-0192-0306

2 Prof. Dr., Pamukkale Üniversitesi, Iktisadi ve İdari Bilimler Fakültesi, iktisat Bölümü, iktisadi Gelişme ve Uluslararası İktisat Anabilim Dalı, asari@pau.edu.tr, ORCID: 0000-0001-9286-2414
} 


\title{
The Transportation Of Fresh Grapes: Example Of Cal Region
}

\author{
Derya Nermin DERELi \\ Aydın SARI ${ }^{4}$
}

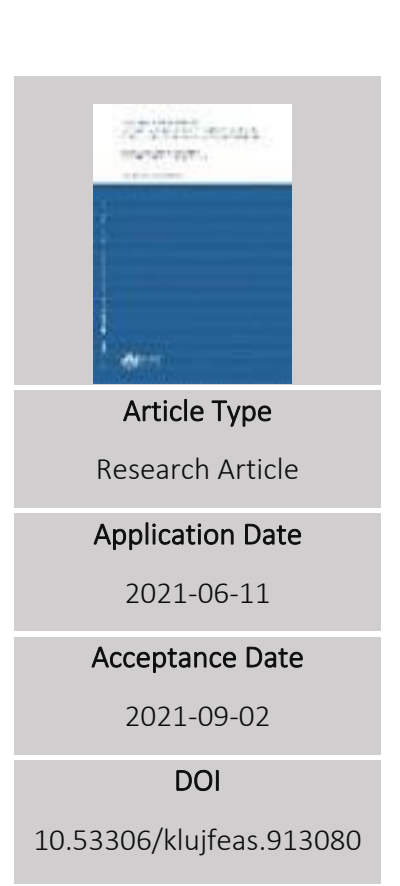

\begin{abstract}
All of the countries in the world search new systems to transport the fresh fruits and vegetables in technological and healthy conditions. By approaching transportation of fresh grapes which grow all of the regions in Turkey we introduce in the article the structure of transportation in Cal-Denizli region. We examine the subject such as depot of the goods synchronous of transportation and packing from mature of the production. It is produced that the vehicles are proper according to world scale on the other hand it is improper the depot of the production and packing in Cal. Particularly, it is seen that insufficient storage and unsuitable packing impress the export of the production negatively. Moreover, there is no transportation by air cargo. It is understood that the exportation from the region by road transportation dominantly. We propose in the result that air cargo should be used more often to develop to the transportation and to minimize the production loss in the fresh fruits and vegetables.
\end{abstract}

Key words: perishable cargo, grapes, transportation of fresh fruit, Denizli Cal region

\footnotetext{
${ }^{3}$ Corresponding Author: Ziraat Yük. Mühendisi, Ege University, Tarım Ekonomisi Bölümü, Tarım Politikası ve Yayım Anabilim Dalı, deryanermin@gmail.com, ORCID: 0000-0002-0192-0306

${ }^{4}$ Prof. Dr., Pamukkale University, Faculty of Economics and Administrative Sciences, Department of Economics, Department of Economic Development and International Economics, asari@pau.edu.tr, ORCID: 0000-0001-92862414
} 


\section{Giriş}

Tarım, insanlığın varoluşuyla birlikte doğmuş ve her çağda varlığı devam etmiş ve de edecek olan bir sektördür. Çünkü tarım, insanların hayatta kalabilmesi ve günlük faaliyetlerini yerine getirebilmesi için gerekli enerjiyi (kalori) sağlayan, besinlerin üretildiği sektördür. Ayrıca bu besinler insan sağlığı için gerekli olan vitamin, mineral, lifler ile antioksidanları da içermektedirler. Tarımın öncelikli işlevi insanların besin ihtiyaçlarını karşılama yönündedir. Bunun yanında tarım, diğer sektörlerin lokomotifi niteliğindedir. Sanayiye hammadde ve sermaye temin etmesi, istihdam, ihracat ve milli gelire katkı sağlaması, toplum sağlığının ve biyolojik çeşitliliğin korunmasına olan katkıları yönleriyle de tarım, toplumun tüm kesimlerini yakından ilgilendiren tüm dünyada vazgeçilmezlik niteliğini koruyan önemli bir sektördür.

Besinlerin üretilmesi kadar nakliyesi ve depolaması da önemli bir süreçtir. Globalleşen dünyada görünmez olan sınırlar, gıda zincirleri için de geçerli durumdadır. Günümüzde üretim sonrası, taşıma işlemi olmadan hemen hemen hiçbir ürün tüketiciye sunulmamaktadır. Tarladan tüketiciye kadar uzanan tüm zincir boyunca ürünlerin kaliteleri bozulmadan ve güvenle nakliye edilebilmeleri için hasat sonrası yönetim uygulamaları önem arz etmektedir. Taze ürünün hasat edilmesinden başlayarak, yüklenmesi, boşaltılması, tartılması, istiflenmesi, sınıflanması, taşınması süreçlerinde yer alanlar ürünlerin güvenliğinin ve kalitesinin sağlanmasında önemli bir role sahiptir. Dünyanın her yerinde hammadde kalitesinin daima korunabilmesi ve tüketilebilir bir durumda son hedefe ulaşması son derece önemlidir (Hsiao vd., 2006).

Birleşmiş Milletler Gıda ve Tarım Örgütü (FAO), insan tüketimi için üretilen tüm gıdaların yaklaşık üçte birinin ya üretim sırasında atılarak ya da mikrobiyal ve kimyasal bozulma nedeniyle hemen hasat sonrasında kaybolduğunu ya da perakendeci veya tüketici davranışları nedeniyle her yıl küresel olarak atıldığını tahmin etmektedir (FAO, 2013).

Ürünün üretim yerinden son tüketiciye ulaştırılırken rotanın belirlemesinde ürünün özellikleri ve nitelikleri, birlikte taşınabilirlikleri ile yol koşulları dikkate alınmalıdır. Taze meyve ve sebzelerin nakliye metodu, ürünün bozulma süresi, değeri ve varış yeri mesafesine göre belirlenir. (Harris, 1988). Tüm bu süreçler değerlendirildiğinde tarımın dinamik bir sektör olduğunu aşikardır. Tarım sektörü içerisinde önemli bir paya sahip alt sektör olan yaş meyve ve sebze üretimi hem Türkiye hem de dünya açısından kritik bir öneme sahiptir. Yaş meyve sebze üretim, tüketim ve dağıtım fonksiyonları ile ekonomi ve istihdama yarattığı kapasite önemli boyutlardadır.

Birleşmiş Milletler Gıda ve Tarım Örgütü (FAO) verilerine göre; dünyada 4 milyar ha tarımsal üretim alanında yaklaşık 867 milyon ton yaş meyve üretimi yapılmaktadır. Türkiye'de ise 37 milyon ha tarımsal üretim alanı bulunmakta ve bu alandan yaklaşık 23 milyon ton yaş meyve üretilmektedir (FAO,2020).

Hasat ve tüketim arasındaki süreçte hem nicel hem de nitel kayıplar meydana gelmektedir. Ürünün besin değeri, yenilebilirlik durumu vb. özellikleri yani taze ürünün tüketici tarafından kabul edilebilirliği niteliksel değerlendirilme kapsamına girerken, süreçte oluşan maddi kayıplar nicelik kaybı olarak değerlendirilmektedir. Kalite standartları, tüketici 
tercihleri ve satın alma gücü ülkeler ve kültürler arasında büyük farklılıklar gösterebilmekte ve hasat sonrası kayıpların büyüklüğünü etkilemektedir.

Biyoaktif bileşiklerin değerinin korunması, taze meyve ve sebzelerin hasat sonrası kalitesinin artırılması giderek önem kazanmaktadır. Doğru çeşitlerin ekilmesi, hasat olgunluk zamanının iyi belirlenmesi, ürünün kendine has özelliğine zarar vermeyen ambalaj malzemesi kullanılması, varış yerine doğru sürede ulaşabilmesi hasat sonrası kayıpların azaltılması yönünde avantajlar sağlamaktadır.

Hasat sonrası kayıpların azaltılması için ürünlerin kalite ve güvenliğinin bozulmasına neden olan faktörlerin belirlenebilmesi önemlidir. Bunun için hasat ve sonrasındaki süreçler için uygun teknolojilere yatırım yapmak ve bunları etkin bir şekilde kullanmak önemlidir. Böylece her bir sürecin izlenebilirliği sağlanarak ekonomik kayıplar azaltılabilir. Ürünlerin kalite ve güvenliğinin sağlanabilmesi için hasat sonrası ihtiyaçların doğru tayin edilerek duruma ve bağlama uygun hasat sonrası teknolojilerin seçiminin yapılması ve hasat-nakliye ve depolama süreçlerinde yer alan personellerin bilgi düzeylerinin arttırılması önemlidir.

\section{Bozulabilir Ürünlerin Nakliyesi}

Diğer malların nakliyesinden farklı olarak yaş meyve ve sebze taşımacılığı müşteri ile nakliyeci arasında iyi bir iletişimi gerektirir. Bozulabilir kargoların taşınmasında nakliyenin planlanmasından nakliye metodunun seçimine paketlemeden soğutmaya sürekli soğuk zincir aşamasını sürdürmeye kadar hassas takip ve yaklaşımlar uygulanmalıdır. Müşterinin istekleri karşılanmalı ve ürün kalitesi için iyi bir planlama yapılmalıdır.

Ürünlerin ambalajlanması, taşınması, depolanması ve satışa sunulmasında "Sebze ve Meyvelerin Toptan ve Perakende Ticaretinde Uyulması Gereken Standart Uygulamalara İlişkin Usul ve Esaslar Hakkında Tebliğde” belirtilen hususların uygulanması şarttır.

Yaş meyve sebze kalitesi uygun olmayan uygulamalarla taşınması ve hijyenik olmayan koşullarda elleçlemenin yapılması ürünlerin çabuk ve kolay bozulmasına neden olur. Taze meyve ve sebzelerin hasattan sonra ön soğutması yapılmış olarak frigorifik nitelikteki araçlarla, soğuk zincirde taşınması nakliye sürecinin etkin yönetimini sağlamada etkilidir. Bu araçlarda sıcaklık, her ürüne uygun olarak ayarlanmalı ve izlenebilir olmalıdır. Birbirlerine zarar verebilecek farklı ürün grupları aynı anda birlikte taşınmamalıdır. Eğer taşınacaksa da taşıma sıcaklığı ile koku ve etilenden etkilenme durumları birbirine yakın ürün grupları oluşturulacak şekilde seçilmelidirler. Ayrıca taşıma araçları, yeterince temizlenmeden farklı herhangi bir maddelerin taşınmasında kullanılmamalıdır. Bu durum ürünleri çapraz kontaminasyona açık hale getirir ve gıda güvenliği ilkelerini bozar.

Işletmeler ürünlerin güvenirliliğini mevzuatlara uygun şekilde sağlamakla yükümlüdürler. Mikrobiyolojik ve kimyasal kriterler Bakanlıkça yayınlanan yönetmeliklere "Türk Gıda Kodeksi Mikrobiyolojik Kriterler Yönetmeliği" ve "Türk Gıda Kodeksi Pestisitlerin Maksimum Kalıntıları Limitleri Yönetmeliği" ne uygun olmalıdır. Yaş meyve ve sebzelerin zararlı organizmalardan korunması için gerekli önlemlerin alınması şarttır. İşletme ürünlerin mevzuatlara uygunluğunun kontrol etmek için bilimsel verilere dayalı testler yaparak süreci analitik bir açıyla izlenmeli ve kayıt altına almalıdır. 
Meyve ve sebzelerin birbirlerine teması, çalışanların elleri ya da hava aracılığı ile çeşitli patojenler, ürünlerin üzerine taşınabilirler. Patojenlerin çoğalmasını önlemek adına bulaşık meyve ve sebzeler, işletme içine alınmadan dışarıda ayıklanarak ortamdan uzaklaştırılmalıdır. Depolama tesislerinde ürün kabul edildiği alan sınırlandırılmalı ve sürekli kontrol edilmelidir. Kullanılan alet ve ekipmanlar işlem aralarında ve gün bitiminde uygun bir dezenfektanla temizlenmelidir. Ayrıca, işletme içinde uygun havalandırma yapılmalıdır. Ürünün korunması amacıyla paketleme, yükleme, taşıma, depolama süreçlerinde çeşitli yollarla patojenin ürüne bulaşması engellenmelidir.

Ambalajlama işlemi için kullanılan materyaller veya gazlar, ürünün güvenilirliğini tehdit etmemelidir. Ambalajlama ürünü herhangi bir kontaminasyondan etkin şekilde koruyacak biçimde yapılmalıdır. Ambalajlanan ürünlerin dışarıda bekletilmesi ürünün kalitesini olumsuz yönde etkileyeceğinden, bekletilmeden uygun sıcaklıklarda depolanmalıdır. Ürünler gruplara ayrılarak hepsi kendi ürün sınıflarına uygun olacak biçimde depolara yerleştirilmelidir. Depolarda istifleme yapılırken deponun kapasitesi düşünülerek depo içerisinde paletler, hava akışının düzenli olarak sağlanabileceği şekilde aralıklı olmasına dikkat edilmelidir.

Ürünün seyahati boyunca ister yurtiçi olsun ister yurtdışı taşıması olsun çevre, seyahat koşulları kötüleşmeye götürebilecek çeşitli uygulamalarla doludur. Nakliye mümkün olduğunca sarsıntısız bir şekilde yapılmalıdır. Ayrıca nakliye araçlarının sıcaklık ve nem kontrolü yapılarak sonrasında da takibi sağlanmalıdır. Taşıma, kapalı araçlarla yapılmalıdır. Satış noktalarına ulaşan ürünler, soğuk zincir kırılmadan, ürünün üzerindeki etiket bilgilerindeki saklama koşulları dikkate alınarak satışa sunulmalıdır. Doğru paketleme, elleçleme, hizmet ve rota seçimi ile etkili soğuk zincir yönetimi hasat sonrası sorunları minimize etmede etkili yöntemlerdir.

Taze meyve ve sebzelerin kalitesi ve kompozisyonu hasat sonrasında gelişen birçok etmen tarafından etkilenmektedir. Tüm meyve ve sebzeler, insanlara benzer biçimde, bir solunum sistemine sahip, canlı biyolojik organizmalardır (Paltrinieri, 2016). Hasattan sonra da yaşam faaliyetleri devam etmektedir. Dolayısıyla bozulabilir besinlerde, dağıtım zincirinin hasat, paketleme, depolama ve nakliye işlemlerinden ve son olarak taze ürünün tüketiciye sunulmasına kadar, her aşamasında nicel kayıplara yol açan niteliksel kayıplar oluşmaktadır.

Bu kalite kayıplarının oluşmasına en etkili faktörler; sıcaklık, terleme ve su kaybı, mekanik hasar ile depoda çürümedir.

Kaliteyi korumak için en verimli yöntem sıcaklık yönetimidir. Sıcaklığın artması bitkide doğal solunum hızının artmasına neden olur. Bu durumda meyve ve sebzeler normalden fazla oksijen tüketerek karbondioksit, su, etilen ve değişken fakat büyük miktarlarda ısı açığa çıkarırlar ve sıcaklık artışı gerçekleşir. Bu olaylar besin stoklarının ve su içeriğinin tükenmesine yol açar. Solunum dinamikleri hasat sonrası olgunlaşma sürecinde ve etilen üretimine direkt olarak etmektedir. Ürünün soğutulması ile solunum hızını yavaşlar ve böylece ürünün raf ömrünü uzar.

Meyve ve sebzelerin su içeriklerinin yüksek olması hasat sonrasında meyve sebze içeriğindeki su varlığının iyi yönetilmesini zorunlu kılmaktadır. Meyve ya da sebze 
bitkisinden koparıldığı zaman buharlaşma meydana gelir. Bu olayın adı terlemedir. Terleme de bitki de su kaybına yol açmaktadır. Bitkilerin kabuk yapısı üzerinde stoma ve lentiseller bulunur. Stoma ve lentisellerin açık veya kapalı olma durumları bitkilerin su içerikleri ve dolayısıyla da ağırlıkları üzerine etkili olmaktadır. Bir bitkinin stoma ve lentiselleri ne kadar fazla hasat sonrası ömrü de o kadar kısadır. Çünkü stoma ve lentiseller sayısının fazla olması su ve kayıpları daha hızlandırmaktadır. Kabuk yapıları ve kabuk üzerindeki gözeneklerin sayı ve dağılımları da türlere ve çeşitlere göre farklılık göstermektedir. Gözenekler üzümde sap çukurunda toplandığı için su kayıpları ve buruşmalar buradan başlar. Su kayıplarının azaltılabilmesi ve hasat sonrası ömrün uzatılabilmesi depolama ve taşıma koşulları fazla su kaybına yol açmayacak şekilde tasarlanmalıdır. Doğal sebepler, yüksek sıcaklık ve düşük nem su kaybını büyük oranda arttırabileceğinden maksimum depolama ömrüne, sadece zarar görmemiş ürünleri, ürünün dayanabileceği en düşük sıcaklıkta ve ürün için en uygun bağıl nem değerinde depolayarak ulaşılabilir. Çok yüksek bağıl nem değerlerinde, hasat edilen meyveler besin değerlerini, görünüşlerini, ağırlıklarını ve tatlarını korurken, bağı nem oranı düşürüldüğünde meyvelerde solma, yumuşama ve sulanma oluşur. (Arah vd., 2015).

Hasat ve sonrasındaki yükleme boşaltma esnasında darbe etkileri meyvelerin ezilmesine, yaralanmasına, sürtünmesine, kesilmesine ya da delinmesine neden olarak mekanik hasarlar meydana getirebilir. Oluşan bu türden zedelenmelerin yarattığı hasarlar ürünün bozulma hızını artıır ve soğuk depolama koşullarında dahi çürütücü organizma ataklarına neden olabilir. Bu durum depolama sürecinde ciddi kayıplar yaratırlar. Dolayısıyla mekanik hasarı azaltarak kayıpları önlemek için, hasat ve hasat sonrası faaliyetlerde meyve ve sebzeleri dikkatle yükleyip boşaltmak önemlidir.

Taze meyve ve sebzelerin depoda çürümesi genellikle mekanik hasarlardan kaynaklanır. Hasar gören yüzey ya da yüzeylerden bakteri ve mantar gibi mikroorganizmaların girmesiyle enfeksiyon oluşur. Bu enfeksiyonların ilk olarak bitkinin büyümesi esnasında tarlada oluşmuş olma ihtimali olsa da bunlar genelde hasat sonrasına kadar fark edilmezler. Bu türden enfeksiyonların görünür hale gelmesi çoğunlukla depolama ve olgunlaştırma sırasında olmaktadır.

Yaş meyve ve sebzeler hasattan sonra da canlılıklarını devam ettiren ürünler oldukları için dikkatsiz ve bilgisiz bir taşınmaları sonucunda genellikle \%60-80 oranında fire verdikleri bilinmektedir. Modern taşımacılıkta; çabuk taşıma, sıcaklık ve nem kontrolünün taşıma süresi boyunca takibi ve ürünlerin zedelemeden taşınması temel ilkelerdir. Yaş meyve ve sebzelerin nakliyesinde kalitenin korunmasında taşıma koşulları önemli rol üstlenmektedir. Bu etki özellikle nakliye süresi uzadığı durumlarda kendini daha net göstermektedir. Yaş meyve ve sebzelerin taşınmasında çeşitli yöntemler kullanılır ve tüm yöntemler kullanılırken hepsinde yükleme ve boşaltma mümkün olduğunca az elden geçmeli ve yaralanmaberelenme oluşturmadan hızlı ve az sarsılmalı bir şekilde taşınmalı, ürünler mümkün olduğunca sıcaktan ve kurutucu etkilerden korunmalıdır.

\section{Türkiye'de Bozulabilir Ürünlerin Nakliyesi}

Taze meyve ve sebzelerin nakliyesi yapılırken gıda güvenliği, ürün kalitesi, çevresel uyum, eğer ihraç edilecekse ihracat yapılacak ülkenin ürün alım şartları dikkate alınmalıdır. 
Depolanmasından taşınmasına kadar özel işlem gerektiren kargolara özel kargolar denilmektedir (IATA, 2016). Son yıllarda bozulabilir kargoların havayolu ile nakliyesi tüm taşıma modları içinde artmaktadır. Özel kargoların nakliyesi hava kargo ile yapılacaksa kargonun kabulü için gönderici sertifikaları istenmektedir. Yüklenmesi etiketlenmesi istiflenmesinde özel kurallar uygulanması gerekmektedir. Hava kargo taşımacılığının artması ekonomik gelişmeyi de hızlandırmaktadır (Ying, Chang ve Hsieh, 2008). Taze meyve ve sebzeler gibi özellikle doğrudan tüketimi de yapılabilen gıda ürünlerinin üzerinde bulunan pestisitler için bir takım dozaj standartları belirlenmiştir. Maksimum kalıntı seviyesi (MRL) olarak isimlendirilen bu dozaj seviyesi hem insan hem de bitki sağlığı ve ayrıca çevre için de önemli bir kriterdir. Örneğin bu maksimum kalıntı seviyesi, Avrupa'ya ihracı yapılacak taze ürünlerde Avrupa Birliği $(A B)^{\prime}$ nin kendi belirlemiş olduğu standartların üstünde çıkarsa, Avrupa, bu ürünleri pazarına kabul etmemektedir. Ürün kontrolleri esnasında bu türden maddelerin bulunması halinde 2073/2005 sayılı Avrupa Tüzüğü (EC)'nde geçen ölçüm limitlerine uygunsuzluk sebebiyle yasal gereklilikleri karşılayamaz ve gıda güvenliğini sağlayamaz. Bu durum ihracatın olmaması, ticari ilişkilerinde sarsılması anlamını taşımaktadır.

Ticaretin de küreselleşmesiyle önem kazanan uzak mesafe taşımacılığı ülkeleri üretim ve ticaretlerinde uygulanacak bazı standartlar belirlemeye itmiştir. Illk olarak 1949 yılında Birleşmiş Milletler Avrupa Ekonomik Komisyonu'nda (BM/AEK) ele alınan "Bozulabilir Ürünler" ile ilgili çalışma, 1962'de OECD tarafından hazırlanan ortak raporla belirlenmiştir. Meyve ve sebze için uluslararası standartların uygulanması bu ürünlerin tanımlanmasını ve fiziksel olarak piyasaya sunulmadan piyasa değerinin anlaşılmasını sağlamaktadır. Taze meyve ve sebze için ürünlerin izlenebilirliği zorunlu hale getirilmiştir. Bu yükümlülüğü yerine getirmek için, ihracatçının tüm meyve ve sebzeler için menşe kanıtı sunması zorunludur. Taşıma senedinde olması istenen belgeler bitki sağlığı sertifikası, paketleme listesi, lot numarası veya GLOBAL.GAP Numarası (GGN) gibi ayırt edici bir izlenebilirlik kodudur. Ayrıca Global Gıda Güvenliği Girişimi (GFSI) tarafından kabul edilen tehlike analizi ve kritik kontrol noktalarına (HACCP) dayalı bir gıda güvenliği yönetim sistemine, GLOBAL.GAP, BRC, IFS, SQF, FSSC 22000, veya endüstri tarafından geliştirilen diğer standartlara uyulması gerekmektedir.

Gıda güvenliği gereksinimlerini, kalite standartlarını ve sertifikaların teminin sağlamak nakliyenin önemli kriterleridir.

\subsection{Türkiye'de Yaş Üzüm Üretimi ve Ürünün Nakliyesi}

Türkiye’ye coğrafi yapısının avantajı ile baktığımızda değişik iklim koşulları, uygun toprak yapısı ve sulanabilir alanlarının çokluğu ile tarımsal yapı varlığının güçlü olduğu bir konumdadır. Bu durum Türkiye'yi taze meyve ve sebzenin üretimin merkezi haline gelebilmesi için gelişmeye zorlamaktadır.

Tarımın önemli kollarından biri olan bağcılık, ülkemizde de önemli bir yere sahiptir. Gerek iklim gerek toprak bakımından bağcılık konusunda elverişli koşullara sahip olan ülkemiz, üzüm yetiştiriciliği bakımından kayda değer bir potansiyele sahiptir. Hemen hemen her toprakta, az su ile yamaç arazilerde bile yetişebilme özelliğine sahip olan üzümün birçok 
değerlendirme şeklinin olması da dikkatleri üzerine daha çok çekmektedir. Özellikle bağcılık konusunda Türkiye' nin son 10 senelik toplam üzüm üretim alanlarına bakıldığında (Tablo 1), dikim alanlarının günümüze doğru yaklaştıkça azaldığı görülmektedir. Buna karşılık üzümün toplam üretim miktarı da benzer paralelde azalmaktadır (Tablo 1).

Tablo 1. Türkiye'de Üzüm Üretim Alanı ve Üretim Miktarı (2010-2020)

\begin{tabular}{ccccc}
\hline \multirow{2}{*}{ YIL } & ALAN (dekar) & & ÜRETIM(TON) & \\
& & TOPLAM & SOFRALIK & ŞARAPLIK \\
\hline 2010 & 4.777 .856 & 4.255 .000 & 2.249 .530 & 461.508 \\
\hline 2011 & 4.725 .454 & 4.296 .351 & 2.268 .967 & 465.320 \\
\hline 2012 & 4.622 .959 & 4.234 .305 & 2.219 .813 & 400.659 \\
\hline 2013 & 4.687 .922 & 4.011 .409 & 2.132 .602 & 455.229 \\
\hline 2014 & 4.670 .929 & 4.175 .356 & 2.166 .749 & 445.127 \\
\hline 2015 & 4.619 .557 & 3.650 .000 & 1.891 .910 & 423.527 \\
\hline 2016 & 4.352 .269 & 4.000 .000 & 1.990 .604 & 472.534 \\
\hline 2017 & 4.169 .068 & 4.200 .000 & 2.109 .000 & 488.000 \\
\hline 2018 & 4.170 .410 & 3.933 .000 & 1.945 .262 & 463.647 \\
\hline 2019 & 4.054 .387 & 4.100 .000 & 2.050 .000 & 451.000 \\
\hline 2020 & 4.009 .979 & 4.208 .908 & 2.218 .056 & 456.353 \\
\hline
\end{tabular}

Kaynak: TÜiK, 2021

Sofralık ve şaraplık çeşitler üzümün yaş olarak kullanıldığı çeşitlerdir. Bu çeşitlerin de alan miktarları paralelinde üretim miktarlarının yıllar içerisinde düştüğü gözlenmektedir. Bu düşüşler üzümün dış ticaretindeki dengelerini de değiş̧irmektedir. Alan ve üretim miktarlarındaki düşüş ithalata yönlendirmekte, ihracatı azaltma eğilimdedir. (Çalışmada yaş üzüm üzerinde durulduğu için kurutmalık üzüm miktarları sadece toplam verilerin içinde yansıtılmıştır.)

Tablo 2'de son 10 yılın ithalat ve ihracat rakamlarına bakıldığında 2018/'19 piyasa yılında üzümün ithalatında büyük artış olduğu gözlenmektedir. İhracat rakamları, ithalata oranla yıllar içerisinde daha az dalgalı bir seyir izlemektedir.

Bitkisel üretim sürecinin gerçekleştiği dönem, çoğu zaman takvim yılı ile birebir örtüşmediğinden, üretim sürecinin dinamiklerini daha iyi temsil eden piyasa dönemi referans dönem olarak kullanılmaktadır. Her bir ürün için referans dönem; ilgili ürünün hasat edilme ve/veya piyasaya sürülme zamanı dönemin başlangıcı kabul edilerek 
belirlenmektedir (TÜiK, 2021). Bu sebeple en son 2019/'20 dönemine ait veriler bulunabilmektedir.

Tablo 2. Türkiye'de Üzüm İthalat ve İhracatı (2010/'11-2019/'20)

\begin{tabular}{ccc}
\hline Piyasa yılı & $\begin{array}{r}\text { Ithalat } \\
\text { (Ton) }\end{array}$ & $\begin{array}{c}\text { Ihracat } \\
\text { (Ton) }\end{array}$ \\
\hline $2010 /$ '11 & 8.920 & 1.092 .592 \\
\hline $2011 /$ '12 & 15.465 & 1.123 .355 \\
\hline $2012 / ' 13$ & 24.047 & 1.187 .218 \\
\hline $2013 / ' 14$ & 14.579 & 971.040 \\
\hline $2014 / ' 15$ & 15.671 & 1.296 .283 \\
\hline $2015 / ' 16$ & 14.303 & 1.003 .453 \\
\hline $2016 / ' 17$ & 8.124 & 1.231 .444 \\
\hline $2017 / ' 18$ & 9.297 & 1.396 .531 \\
\hline $2018 / ' 19$ & 131.285 & 1.339 .499 \\
\hline $2019 / ' 20$ & 11.460 & 1.196 .791 \\
\hline
\end{tabular}

Kaynak: TÜik, 2021

TÜik üretim denge tablosundan Türkiye'de üzümün üretim kayıpları ile üretim, nakliye, işleme ve depolama süreçlerindeki toplam kayıplara Tablo 3'te yer verilmiştir. Toplam kayıpların içinde ürünün hasat edilmesi sırasında ve hasat edilen ürünün çiftlik avlusuna getirilinceye kadar meydana gelen kayıplar yani üretim kayıplarının oranları yüksektir.

Ürünün çiftlik avlusuna getirilmesinden sonraki süreçte taşınması, işlenmesi ve depolanması sırasında meydana gelen kayıplar yani toplam kayıpların içinden üretim kayıplarını çıkardığımızda geriye kalan süreçlerdeki kayıplar da üretim kayıplarının oranlarına yakındır (Tablo 3).

Tablo 3. Türkiye'de Üzüm Üretim Kayıpları ve Toplam Kayıplar (2010/'11-2019/'20)

\begin{tabular}{cccc}
\hline Üretim & & kayıpları \\
(Ton) & Kayıplar (Ton) & $\begin{array}{c}\text { Top. Kayıplar / Üretim } \\
\text { Kayıpları (\%) }\end{array}$ \\
\hline $2010 /$ '11 & 123.395 & 244.443 & 50.48 \\
\hline $2011 /$ '12 & 124.594 & 248.435 & 50.15 \\
\hline
\end{tabular}




\begin{tabular}{llll}
\hline $2012 / ' 13$ & 122.795 & 230.401 & 53.30 \\
\hline $2013 / ' 14$ & 116.331 & 239.463 & 48.58 \\
\hline $2014 / ' 15$ & 121.085 & 222.527 & 54.41 \\
\hline $2015 / ' 16$ & 105.850 & 201.141 & 52.62 \\
\hline $2016 / ' 17$ & 116.000 & 219.371 & 52.88 \\
\hline $2017 / ' 18$ & 121.800 & 212.148 & 57.41 \\
\hline $2018 / ' 19$ & 114.057 & 210.487 & 54.19 \\
\hline $2019 / ' 20$ & 118.900 & 225.157 & 52.81
\end{tabular}

Kaynak: TÜiK, 2021

Kayıpların başlıca nedenleri; hasattan sonraki dönemde oluşan hastalıklara bağlı çürümeler, ön soğutma yapılmaması, kontrollü atmosferde muhafazanın sağlanmaması, uygun paketleme, elleçleme ve taşınmanın yapılmamasıdır. Dünya genelinde gıda ürünlerinin kabaca üçte biri kaybedilmektedir. Bu kayıpların büyük çoğunluğu ürünün nakliyesi esnasında olmaktadır (Lin, Negenborn ve Lodewijks, 2015).

Bu kayıplara bakıldığında hem üretim sürecinin yeniden planlanması ihtiyacı hem de üretim sonrasında ürünün taşınması, işlenmesi ve depolanması süreçlerinin daha iyi yönetilmesi ihtiyacı açıktır.

Soğuk zincir, üretim merkezinden tüketim noktasına kadar, termal veya soğutulmuş paketleme yöntemlerini içeren, ürünlerin raf ömrünü artırmak ve kalitesini korumak amacıyla bozulabilir ürünlere en ideal koşulları sağlayan lojistik sistemdir (Saurav, 2014). Nakliye sırasında soğuk zincir yönetimi önemlidir. Yükleme aşaması, soğuk zincirin kolaylıkla bozulabileceği bir aşama olduğu için özellikle dikkat edilmesi gereken bir süreçtir. Entegre bir soğuk zincir taze gıda ürünlerinin paketlenmesi ve soğutulmasını, gıda işlemeyi, soğuk depolamayı, soğuk nakliye ve sıcaklığın kontrol edildiği koşullarda geçici depolama ve sonrasında dağıtımını, toptan marketlerde, perakende marketlerde ve yemek servisi işletmelerinde ürünün buzdolabı ya da donduruculu depolarda muhafazasını içermektedir.

Soğutma işlemi bozulabilir ürünlerde solunumu azaltır, bozulma ve doğal olgunlaşma oranlarını düşürür, terlemeyi azaltır, su kaybını düşürür ve buna bağı olarak buruşmayı azaltır, etilen etkisine direnç geliştirerek üretimini azaltır dolayısıyla olgunlaşmayı yavaşlatır, mikroorganizmaların faaliyetlerini azaltır kararma, doku, tat ve besin değeri kayıplarını azaltır (Kitinoja ve Kader, 2015).

Soğuk zincir sürecinin her aşamasında, ürün tavsiye edilen en düşük depolama sıcaklığında tutulmalıdır. Elle müdahale sırasında ürün ısınsa bile, bozulabilir ürünlerinin yüklenip boşaltılması sırasında, ürün mümkün olduğu kadar uzun süre soğuk tutulmalıdır. Bazı durumlarda ısı sadece dış kaynaklardan değil, ürünün paket içerisinde kendi solunumu ile üretiminden kaynaklanabilmektedir. Bu durum paketlemenin öneminin bir göstergesidir. 
Başta domates olmak üzere yeşil yapraklı sebzeler ve şeftali gibi yumuşak kabuklu ve sulu meyveler, bitki ve insan patojenleri tarafından çapraz kontaminasyona daha yatkındır. Hasarlı, hastalıklı ve fazla olgun meyvelerin nakliyesi yapılması doğru değildir. Bu ürünlerin, başka ürünler yüklemeden önce, nakliye konteynerlarından çıkarılması şarttır.

Eğer lojistik olarak karma yüklenmesi gereken ürünler varsa öncelikli olarak, bunların sıcaklık ve nem ihtiyaçlarının, etilen duyarlılıklarının ve koku emme kapasitelerinin birbirleriyle olan uygunluğu kontrol edilmelidir. Örneğin etilen üreten ürün ile etilene duyarlı ürün arasındaki uyumsuzluk büyük ürün kayıplarına neden olmaktadır (IATA, 2016).

Bozulabilir mallar karayolu veya demiryolu ile araç ya da konteyner ile taşınabilir. Ürün sahibi hangi taşıma modunu seçerse seçsin nakliyeci ile malın yapısı ve özellikleri konuşarak ürünün kalitesini bozmadan uygun taşıma ve teknolojisi ortaya çıkabilir. En iyi planlamayı da yapsanız karayolu ve demiryolu taşıma programı kötü hava ve mekanik arıza gibi faktörlere bağlı olarak aksamalarla karşılaşabilir.

Soğutucu araçlar ve konteynerler ürünü belli sıcaklıkta tutmak için dizayn edilmiştir. Sıcaklığı yüksek ürünlerin soğutmak için değil bu bakımdan yükleme yapılmadan önce ürünlerin ön soğutması yapılmalıdır. Full konteyner ( $F C L)$ yüklemelerde, Konteyner taşıma kapasitesi dikkate alınarak yükleme yapılmalıdır. Ayrıca karayolu taşıma ağırlığı kurallarına uyulmalıdır. Karayolu demiryolu kombine taşıma yapılacak ise kurallar dikkate alınmalıdır.

Parsiyel taşımalarda ( $L C L)$ organizasyonu forwarder yapmaktadır. Bu nedenle diğer ürünlerle konsilide edilebilmektedir. Diğer ürünlerin soğuk hava derecesi ile uygun Isı yakalanmalıdır. Ayrıca diğer ürünlerdeki kötü etkileşimin önüne geçmeniz gerekir. Örneğin, etilen üreten elma veya olgunlaşmış muz brokoli ve kesme çiçek gibi etilene duyarlı ürünler ile aynı ortamda taşınmamalıdır. Üzümde hasat sonrası su kaybına bağlı kalite düşüşünü engellemek için nakliye aracı kısa sürede soğutulmalı ve yükleme esnasında nakliye aracının sıcaklığı maksimum $5^{\circ} \mathrm{C}$, minimum $-1^{\circ} \mathrm{C}$, bağıl nem oranı $\% 90-95$ ve su oranı ise $\% 76-88$ olmalıdır.

Şarap üzümleri (Vitisvinifera L.), düşük fizyolojik faaliyet oranına sahip klimakterik olmayan meyvelerdir. Hasat sonrası ciddi oranda su kaybederler. Şaraplık üzümler soğuğa karşı dirençlidirler. Etilen varlığında, üzümlerde ve saplarda Botrytis cinerea (gri küf) gelişmesi olabilmektedir. Şarap üzümlerinde solunum yoğunluğunun depolama sıcaklığıla birlikte arttığını gözlemlemiştir (Perkins ve Veazie, 2002).

Sofralık üzümler de soğuğa karşı dirençlidirler. Etilene karşı çok hassas değildirler. Sofralık üzümlerde sap solunumu, tane solunumuna kıyasla yaklaşık 15 kat daha yüksektir. Hasat sonrası dönemde, meyveler -0.5 ile $0{ }^{\circ} \mathrm{C}$ arasındaki bir sıcaklıkta depolanmalıdırlar (Crisosto ve Smilanick, 2004). SO2 bozulma kontrolü için kullanılmaktadır. Havada \%10 ile 15 arasındaki CO2, bitki çeşidine bağlı olarak, 2 ile 4 hafta arasındaki bir zaman diliminde gri küfün oluşumunu kontrol etmek için kullanılabilir (Crisosto ve Smilanick, 2004).

\section{2. Çal'da Yaş Üzüm Üretimi ve Ürünün Nakliyesi}

Üzüm üretimi için de uygun iklim ve toprak koşullarına sahip olan Türkiye'de bağcılık önemli bir ekonomik güce sahiptir. Pazara uzaklık ve tüketim şekilleri dikkate alınarak hem ürünü 
koruyacak hem de tüketici beğenilerine uygun olacak kabuk yapısına sahip çeşitlerin ön plana alınmaktadır. Aynı şekilde yetiştirilecek çeşit seçimi de önemlidir.

Çal bölgesinde üzüm yetiştiriciliğine elverişli iklim ve toprak yapısı ile uzun yıllardır bağcılık yapılan bir yerdir. Kendine özgü endemik (Çalkarası) çeşidi ile üzüm konusunda dikkatleri daha da üzerine çekmektedir. Bölgeye özgü bu güzel endemik çeşit özellikle şaraplık ve kurutmalık olarak tercih edilmektedir, fakat dokunmaya karşı hassasiyeti büyüktür. Dolayısıyla depolama, paketleme ve nakliye işlemleri konusunda zorluklar yaşanmaktadır.

Çal bölgesi üretim alanlarına baktığımızda son yıllardaki toplam dikim alanları gibi bölgede de üretim alanlarında azalma olduğu açıktır (Tablo 4). Çal bölgesi, Türkiye'deki üretim alanlarının ortalama \%4'ünü oluşturmaktadır (Tablo 4). Bölgenin yetiştiricilik potansiyeli göz önüne alındığında bu düşük bir orandır. Bölgenin potansiyeli doğrultusunda üretime elverişli fakat atıl kalmış alanların üretime açılması hatta yeni üretim alanlarının düzenlenmesi çalışmaları yapılarak Çal bölgesinin Türkiye içindeki ortalamasının arttırılması yönünde ilerlemek akıllıca olacaktır.

Tablo 4. Türkiye'de ve Çal Üzüm Üretim Alanları, (Dekar) (2010-2020)

\begin{tabular}{lccc}
\hline YIL & Denizli(Çal) & Türkiye & Oran \% \\
\hline 2010 & 122.00 & 3.437 .214 & 3.5 \\
\hline 2011 & 122.00 & 3.413 .553 & 3.6 \\
\hline 2012 & 122.00 & 3.294 .283 & 3.7 \\
\hline 2013 & 120.60 & 3.337 .033 & 3.6 \\
\hline 2014 & 120.50 & 3.326 .527 & 3.6 \\
\hline 2015 & 116.50 & 3.287 .328 & 3.5 \\
\hline 2016 & 116.20 & 3.049 .558 & 3.8 \\
\hline 2017 & 117.88 & 2.875 .092 & 4.1 \\
\hline 2018 & 110.63 & 2.831 .629 & 3.9 \\
\hline 2019 & 108.38 & 2.771 .397 & 3.9 \\
\hline 2020 & 104.89 & 2.725 .356 & 3.8 \\
\hline
\end{tabular}

Kaynak: TÜiK, 2021

Üzüm verimlerine bakıldığında Çal bölgesinin Türkiye'deki üzüm verimlerine oranının hayli yüksek olduğu açıktır ve ortalaması \%50'nin üzerinde kalmaktadır (Tablo 5). Verilere göre Çal'ın üzüm veriminde Türkiye için önemli bir bölge olduğu söylenebilir. 
Tablo 5. Türkiye'de ve Çal Üzüm Verimleri (kg/da) (2010-2020)

\begin{tabular}{lccc}
\hline YIL & Denizli(Çal) & Türkiye & Oran \% \\
\hline 2010 & 1.525 & 2.909 & 52.42 \\
\hline 2011 & 2.084 & 2.993 & 69.63 \\
\hline 2012 & 1.946 & 3.050 & 63.80 \\
\hline 2013 & 1.858 & 2.813 & 66.05 \\
\hline 2014 & 2.890 & 3.059 & 94.48 \\
\hline 2015 & 1.755 & 2.941 & 59.67 \\
\hline 2016 & 2.540 & 3.207 & 79.20 \\
\hline 2017 & 2.800 & 3.557 & 78.72 \\
\hline 2018 & 2.885 & 2.981 & 96.78 \\
\hline 2019 & 3.575 & 3.576 & 99.97 \\
\hline 2020 & 2.245 & 3.552 & 63.20 \\
\hline
\end{tabular}

Kaynak: TÜik, 2021

Çal bölgesinin üzüm üretim miktarları, Türkiye'deki üzüm üretim miktarlarına oranı 2019 yılında en yüksek seviyesine ulaşsa da \%6'nın üstüne çıkamamıştır (Tablo 6).

Tablo 6. Türkiye ve Çal Üzüm Üretim Miktarları (Ton) (2010-2020)

\begin{tabular}{lccc}
\hline YIL & Denizli(Çal) & Türkiye & Oran \% \\
\hline 2010 & 65.050 & 2.711 .038 & 2.40 \\
\hline 2011 & 83.500 & 2.734 .287 & 3.05 \\
\hline 2012 & 81.044 & 2.620 .472 & 3.09 \\
\hline 2013 & 75.774 & 2.587 .831 & 2.93 \\
\hline 2014 & 116.133 & 2.611 .876 & 4.45 \\
\hline 2015 & 69.947 & 2.315 .437 & 3.02 \\
\hline 2016 & 98.353 & 2.463 .138 & 3.99 \\
\hline 2017 & 112.225 & 2.597 .000 & 4.32 \\
\hline 2018 & 88.631 & 2.408 .909 & 3.68 \\
\hline
\end{tabular}




\begin{tabular}{llll}
\hline 2019 & 127.270 & 2.501 .000 & 5.09 \\
\hline 2020 & 78.230 & 2.674 .409 & 2.93
\end{tabular}

Kaynak: TÜiK, 2021

Çal bölgesinin iklim ve toprak yapısı bakımından elverişli koşulları ile bölgede uzun yıllardır üzüm yetiştiriciliğinin yapılıyor olmasının bölgenin potansiyelini canlandırmaya yeterli olmadığı gözlenmektedir. Bölgedeki üzüm yetiştiriciliğinin arttırılması ve bu artışın sürdürülebilir, ekonomik büyümeye ve toplumsal refaha katkı sağlayabilir olması için ihracatçıların ve girişimcilerin desteklenerek rekabet gücünü yükseltecek yenilikçi yetiştirme ve nakliye politikaları oluşturulması şarttır.

\section{Sonuç}

Çal bölgesinde üzüm yetiştiriciliğine elverişli iklim ve toprak yapısı ile uzun yıllardır bağcılık yapılan bir yerdir. Kendine özgü endemik (Çalkarası) çeşidi ile üzüm konusunda dikkatleri daha da üzerine çeken bölgede, yetişen üzümlerin nakliye, depolama, ambalajlama konularında eksikleri mevcuttur. En önemli eksikliklerden biri ürünlerin depolanmasıdır. Bölgede sadece iki tane soğuk hava deposu bulunmaktadır. Depo işletmeleri sayesinde yurtdışına ürün sevkiyatı yapılmaktadır. Bu işletmeler tarafından ihracata ürünler gönderilmektedir. Soğuk hava depolarında sadece üzüm değil diğer ürünlerde bulunmaktadır. Depolanan çeşitli ürünler arasında ağılığı sofralık üzümler almaktadır. Üzüm gibi nakliyeye dayanıklı ürünlerin depolama talepleri yüksektir. Bununda sebebi sofralık üzümlerin depolama, paketleme ve nakliye hassasiyetlerinin daha kontrol edilebilir seviyede olmasıdır. Depo işletmesi yapan firmalarla yapılan yüz yüze görüşmede yetkililer verim dalgalanmalarının olduğunu söylemektedir. Bahsi geçen bu iki firmada bölgede yetişen üzümlerin verim düşüşlerinin ihracat rakamlarına yansıdığını belirtmektedir.

Türkiye'de bir çok bölge ile karşılaştırıldığında ege bölgesi ve Çal coğrafyasında özellikle üzüm üretimi ve dağıtımı gelişmiştir. Ürün nakliyesi konusunda hassas olan bölge ürün zayiatı açısında düşük kalmaktadır. Ayrıca ürünün kurutulması pekmez yapımı gibi alternatifler açısından zenginlik taşımaktadır. Firmalar ürünlerin nakliyesini ön soğutma yaparak frigorifik araçlarla yaptıklarını bildirmişlerdir. Ürünlerin taşınması için karayolunu tercih eden firmalar, yüksek maliyetlerden dolayı hava kargoyu tercih etmediklerini, hava kargo masraflarının karayolu nakliyesine göre birim alanda yaklaşık 10 kat daha yüksek olduğunu belirtmişlerdir.

Tüm Türkiye'de olduğu gibi Çal bölgesinde de yurtiçi ve yurtdışına sebze meyve taşımacılığı karayolu ile yapılmaktadır. Özellikle havayolu taşımacılığının daha yüksek maliyetli olması ve hava kargonun her bölgede olmaması hızlı ve yaygın küçük ölçekli taşımacılığın sebze ve meyve taşımacılığının istediği küçük miktarlarda taşımacılığın yapılamaması anlamına gelmektedir. Meyveye olan talep ani ve küçük miktarlarda olabilmektedir. Sezona göre yurtdışında bir ülkeden 100 kg talep gelebilmektedir. Ancak hava kargo taşımacılı̆̆ı olmadığı zaman bu talepler karşılanamamaktadır. Bu nedenle ege bölgesinde hava kargo terminallerinin her ilde yaygınlaştırılması gerekmektedir. 
Bahsi geçen depo işletmeciliği yapan iki firma orta ölçekte firma olduklarından depolama, paketleme ve nakliye maliyetlerini etkili bir gelir-gider yönetimi ile karşılayabilirler fakat küçük üreticilerin ürünlerini uygun koşullarda depolaması, paketlemesi ve nakliye edebilmesi ancak etkili bir örgütlenme ile sağlanabilecektir. Bu noktada özellikle küçük üreticilerin devletin teşvik ve yardımlarına intiyaçları vardır. Küçük ve dağınık yapıda olan arazilere sahip bölgede üreticilerin tarımsal üretimleri de küçük ölçekte olduğu için ancak yetiştiricilerin etkili bir organizasyon içinde örgütlenmeleri ve gerekli alt yapı tesislerini kurulumuyla gerçekleşebilir. Üreticilerin örgütlenmesi ve faaliyetlerinde etkin bir konuma gelebilmelerindeki en etkili yöntem tüm gelişmiş ekonomilerde olduğu gibi kooperatifler kurmaktır. Küçük üreticiler ancak kooperatifler aracılı̆̆ıyla modern ve ekonomik ölçekli bir depolama, paketleme ve nakliye yapısına kavuşabileceklerdir. Hem küçük üretici hem de daha büyük ölçekteki firmalar için depolama, paketleme ve nakliye faaliyetlerinde devlet teşvik ve yardımları gereklidir.

Çal bölgesinde üzüm yetiştiriciliğinin sürdürülebilir olması, ekonomik büyümeye ve toplumsal refaha katkı sağlayabilmesi için ihracatçıların ve girişimcilerin desteklenerek rekabet gücünü ve ticari iş birliğini arttıracak etkin, hızlı ve insan odaklı yetiştirme ve nakliye politikaları oluşturulması ve bu politikaların yenilikçi bir yaklaşımla gerçekleştirilmesi, uygulanması ve koordine edilmesi şarttır.

\section{"Yaş Üzüm Nakliyesi: Denizli Çal Bölgesi Örneği“" Başlıklı Makalenin Araştırma ve Etik Beyanı Bilgileri}

\begin{tabular}{|c|c|}
\hline & $\begin{array}{c}\text { Bu çalışma "Araştırma ve Yayın Etiği" değerlerine uygun olarak } \\
\text { hazırlanmıştır }\end{array}$ \\
\hline Bilgilendirme & $\begin{array}{l}\text { Çalışma herhangi bir bildiri veya tez benzeri çalışmadan üretim } \\
\text { değildir. }\end{array}$ \\
\hline $\begin{array}{l}\text { Yazar Çıkar } \\
\text { Çatışması Beyanı }\end{array}$ & Çalışmada herhangi bir çıkar çatışması bulunmamaktadır. \\
\hline $\begin{array}{l}\text { Yazar Katkı Oranı } \\
\text { Beyanı }\end{array}$ & $\begin{array}{l}\text { Çalışmada Aydın SARı \%50 oranında, Derya Nermin DERELi \%50 } \\
\text { oranında katkıda bulunduğu beyan edilir. }\end{array}$ \\
\hline Teşekkür & Çalışmada teşekkür gerektiren bir durum bulunmamaktadır. \\
\hline $\begin{array}{l}\text { Etik Kurul Onay } \\
\text { Belgesi }\end{array}$ & Çalışmada etik kurul onayı gerekmemektedir. \\
\hline
\end{tabular}




\section{Kaynakça}

Arah,I.K., Amaglo,H., Kumah,E.K., Ofori, H. (2015). Preharvest and Postharvest Factors Affecting the Quality and Shelf Life of Harvested Tomatoes: A Mini Review. International Journal of Agronomy, http://dx.doi.org/10.1155/2015/478041.

Crisosto, C.H. and Smilanick, J.L., (2004). Grape (table).The Commercial Storage of Fruits, Vegetables and Florist and Nursery Stocks.

FAO, (2013). Food Wastage Footprint. Impacts on Natural Resources. Summary Report.

FAO, (2020). World Food and Agriculture-Statistical Yearbook 2020. http://www.fao.org/3/cb1329en/CB1329EN.pdf

Haris. R.H. (1988). Production is Only Half The Battle - A Training Manual in Fresh Produce Marketing for the Eastern Caribbean, Food And Agriculture Organisatıon Of The United Nations, Bridgetown, Barbados.

Hsiao, H. I., van der Vorst, J. G., \& Omta, S. W. F. (2006), "Logistics Outsourcing in Food Supply Chain Networks: Theory and Practices", International Agri-Food Chains And Networks, 135.

IATA Perishable Cargo Regulation 15th Edition 2016.

Kitinoja, L., Kader, A. (2015). Measuring Postharvest Losses in Fruits and Vegetables in Developing Countries. 10.13140/RG.2.1.3921.6402.

Lin Xiao, Negenborn Rudy R., Lodewicks Gabriel, Survey on Operational Perishables Quality Control and Logistics, Springer International Publishing Switzerland 2015.

Paltrinieri, G. (2016). Handling Fruits, Vegetables and Root Crops, Food and Agriculture Organization of United Nations. The United Nations, Bridgetown, Barbados.

Perkins-Veazie, P. (2002). Grape (Muscadine). Agricultural Research Service, Beltsville, Md. Draft version of revised USDA Agriculture Handbook, 66.

Saurav, N. (2014). Supply Chain Efficiency: An Insight from Fruits and Vegetables Sector in India. Journal of Operations and Supply Chain Management. 7. 154. 10.12660/joscmv7n2p154-167.

Tüik, (2021).https://data.tuik.gov.tr/Bulten/Index?p=Bitkisel-Urun-Denge-Tablolari-20192020-37246

TÜik, (2021). https://biruni.tuik.gov.tr/medas/?kn=92\&locale=tr

TÜiK, (2021). https://data.tuik.gov.tr/Kategori/GetKategori?p=tarim-111\&dil=1

Ying Yung Hstang, Chang Chun PIng and Hsieh Meng Chi, Air Cargo as Impetus for Economic Growth Through the Channel of Openness: The Case of OECD Countries International Journal of Transport Economics, Vol. Xxxv, No: 1, February 2008. 